\title{
Effects of pectin and tomato paste as a natural antioxidant on inhibition of lipid oxidation and production of functional chicken breast sausage
}

\author{
Mohammad JOUKI ${ }^{1 \star}$ (D), Mohammad RABBANI ${ }^{2}$, Mohammad Javad SHAKOURI ${ }^{1}$
}

\begin{abstract}
In this study antioxidant effects of pectin and tomato paste (TP) on lipid oxidation and production of functional chicken breast sausage during refrigerated storage for 14 days were evaluated. Raw chicken sausage samples were enriched with different levels of TP containing $0,1,2$ and $10 \%$ and $1 \%$ pectin, and peroxide value (PV), thiobarbituric acid reactive substances (TBARS) and sensory attributes were evaluated periodically for 14 days of storage at $4{ }^{\circ} \mathrm{C}$. Although after 1 day of storage TP treatments at level of $1 \%$ did not exert any antioxidant effects on TBARS, PV varied for all treatments except control and remained lower than $8 \mathrm{meq} \mathrm{O} / \mathrm{kg}$ throughout the storage time. During refrigerated storage, formation of lipid oxidation products increased from 2.8 to $15.2 \mathrm{meq} \mathrm{O} 2 / \mathrm{kg}$ for PV and 0.064 to $0.38 \mathrm{mg}$ malondialdehyde (MDA) $/ \mathrm{kg}$ in the TBARS test, respectively. At the end of storage time, the PV and MDA value in chicken sausage treated with $1 \%, 2 \%$ and $10 \%$ TP decreased by 51 and $19 \%$, 73 and $69 \%$, and 71 and $82 \%(\mathrm{P}<0.05)$, respectively. The results of sensory evaluation showed that panelists preferred functional sausage containing $2 \%$ of TP and higher levels of TP altered the visual appearance of product.
\end{abstract}

Keywords: chicken breast sausage; lipid oxidation; tomato antioxidants; TBARS value.

Practical Application: One of the most important reasons for the decrease quality and taste of fatty foods is the formation of lipid oxidation compounds that can increase economic losses due to poor product quality. The tomato paste has an antioxidant effect which can be considered one option for reduction of the lipid oxidation in this raw chicken meat product. Therefore, application of TP on the raw chicken sausage can lead to a better preservation of meat product.

\section{Introduction}

Lipid oxidation in meat products is affected by various factors including fat content, amino acid profiles, processing rate, storage conditions as well as antioxidant content (Marzoni et al., 2014). One of the most important reasons for the decrease quality and taste of fatty foods is formation of lipid oxidation compounds that can increase economic losses due to poor product quality (Maqsood \& Benjakul, 2011), which can precipitate health hazards and economic losses in terms of inferior product quality (Naveena et al., 2008). As it has been mentioned by Masuda et al. (2001) and Kumar et al. (2015), natural antioxidants can donate the hydrogen radicals to pair with other available free radicals and inhibit the propagation reaction throughout the lipid oxidation process. Nowadays, increasing knowledge and demand for natural ingredients and negative attitude to some synthetic antioxidants have led to increased demand for the use of natural sources containing antioxidants in meat industry (Kumar et al., 2015). Meanwhile, vegetables, Fruits and other plant materials are good alternatives.

Tomato (Lycopersicon esculentum L.) is one of the world's major vegetable that is an excellent source of many nutrients and secondary metabolites that are important for human health; vitamins $\mathrm{C}$ and $\mathrm{E}, \mathrm{B}$-carotene, lycopene, phenols, flavonoids, organic acids and phenolics (Giovanelli \& Paradiso, 2002). Much research has been performed to reduce the risk of prostate cancer due to the consumption of tomatoes and their products (Xu et al., 2016; Chen et al., 2013; Gann et al., 1999).

Tomato is widely consumed and can provide a significant proportion of the total antioxidants in the diet (Martinez-Valvercle et al., 2002). Elbadrawy \& Sello (2016) studied the antioxidant activity of tomato by the determination of peroxide value, malondialdehyde, DPPH and Carbonyl content. They showed that aqueous and hydroalcoholic extracts of tomato have a good antioxidant activity as compared to butylated hydroxy toluene (BHT), an artificial antioxidant. Therefore, tomato extract significantly decreased the peroxide and malondialdehyde values in the oil samples (Elbadrawy \& Sello, 2016).

Malondialdehyde (MDA) is a product resulting from the oxidative degradation of unsaturated fatty acids in the cell membrane (caused by lipid peroxidation) (Elbadrawy \& Sello, 2016). Improvement of lipid stability in meat has been stated in several studies. Kim et al. (2013) investigated the inhibition of lipid oxidation in raw beef patties by chamnamul and fatsia extracts. They showed that beef patties treated with extracts of chamnamul (Pimpinella brachycarpa) and fatsia (Aralia elata) (0.5-1.0\%) had lower MDA values compared with control beef patties after 12 days of storage $(P<0.05)$. The antioxidant activity of grape seed extract (Brannan, 2008), sage and garlic 
(Mariutti et al., 2011), oregano (Jouki et al., 2014a, b), and various other spices (Murcia et al., 2004; Du \& Li, 2008) in meat and poultry products has been well demonstrated. Recently, Nachtigall et al. (2019) showed that using $\mathrm{KCl}$ and $\mathrm{CaCl}_{2}$ instead of $\mathrm{NaCl}$ can reduce lipid oxidation and maintain the quality of bovine raw meat. Several reports claimed that cold storage combined with minimal processing improves the poultry meat shelf life (Marcinkowska-Lesia et al., 2016; Jouki, 2013; Jouki \& Tabatabaei-Yazdi, 2014a, b). No data has been published on the limitation of lipid oxidation in raw chicken breast sausage by enrichment with tomato paste. Therefore, the aim of this study was to investigate the effect of tomato paste on the inhibition of lipid oxidation in functional chicken sausage.

\section{Materials and methods}

\subsection{Preparation of tomato paste}

The ripe tomatoes were selected and washed to remove contaminants. Then tomatoes were blanched in hot water by hot break processing. Briefly, the tomatoes were pre-heated at about $85^{\circ} \mathrm{C}$ for $5 \mathrm{~min}$ to inactive enzymes and easy peeling of the skin. The tomatoes were cooled with water and the skin was peeled off and pulped in a blender. The pulp was heated in an open pot at $90^{\circ} \mathrm{C}$ for $1 \mathrm{~h}$ to concentrate the paste (Figure 1). The samples were then hot-filled in glass containers. Then the containers were cooled with cold water and kept in the refrigerator at $4{ }^{\circ} \mathrm{C}$ for testing.

\subsection{Antioxidant activity of tomato paste}

The DPPH (2, 2-diphenyl-1-picrylhydrazyl) method is used for the determination of free radical scavenging activity, usually expressed as $\mathrm{IC}_{50}$ (Kim \& Chin, 2017). Briefly, $2 \mathrm{~mL}$ of DPPH ethanol solution (freshly prepared at a concentration of $0.1 \mathrm{mM}$ ) were added to $2 \mathrm{ml}$ of extract solution at various levels $(10-100 \mu \mathrm{g} / \mathrm{mL})$. The resulting mixture was stored in the dark place for $30 \mathrm{~min}$ at $20^{\circ} \mathrm{C}$ and afterward absorbance of samples was measured at $517 \mathrm{~nm}$ against ethanol. L-ascorbic acid was used as the reference. The free radical scavenging activity of DPPH radicals was calculated according to the following Equation 1:

$$
\text { Antioxidant Activity }(\%)=\frac{(\text { absorbance of dpph_absorbance of sample })}{\text { absorbance of } d \text { pph }} \times 100
$$

The coriander extract concentration providing $\mathrm{IC}_{50}$ was measured using plotting concentrations against percentage inhibition. The amount of antioxidant needed to reduce the initial concentration of DPPH by $50 \%$ is defined as $\mathrm{IC}_{50}$, and lower amounts of $\mathrm{IC}_{50}$ indicate higher antioxidant activity.

\subsection{Preparation of functional chicken sausage samples}

Raw chicken breasts were purchased from a local supermarket in Tehran, Iran. Chicken breasts sausage was processed as described by Jo et al. (2018). Briefly, excess fat was trimmed and the remaining meat was cut into inch cubes. The chicken breasts cubes were minced using a Kitchen Aid food grinder and then, were separated into four groups. Mass of $200 \mathrm{~g}$ minced chicken meat was mixed with $40 \mathrm{~g}$ shattered ice, $0.6 \mathrm{~g}$ salt (sodium chloride), $0.6 \mathrm{~g}$ sodium polyphosphate, $0.1 \mathrm{~g}$ monosodium glutamate. The pectin was added at $1 \%$ and tomato paste was added at $0 \%$ (control) and 1, 2 and $10 \%(\mathrm{w} / \mathrm{w})$ based on total weight of minced chicken. Each sausage portion was divided in 60 polyethylene bags containing two portions of $25 \mathrm{~g}$ each, packed and stored at $4{ }^{\circ} \mathrm{C}$ for 14 days.

\section{Receiving the tomatoes}
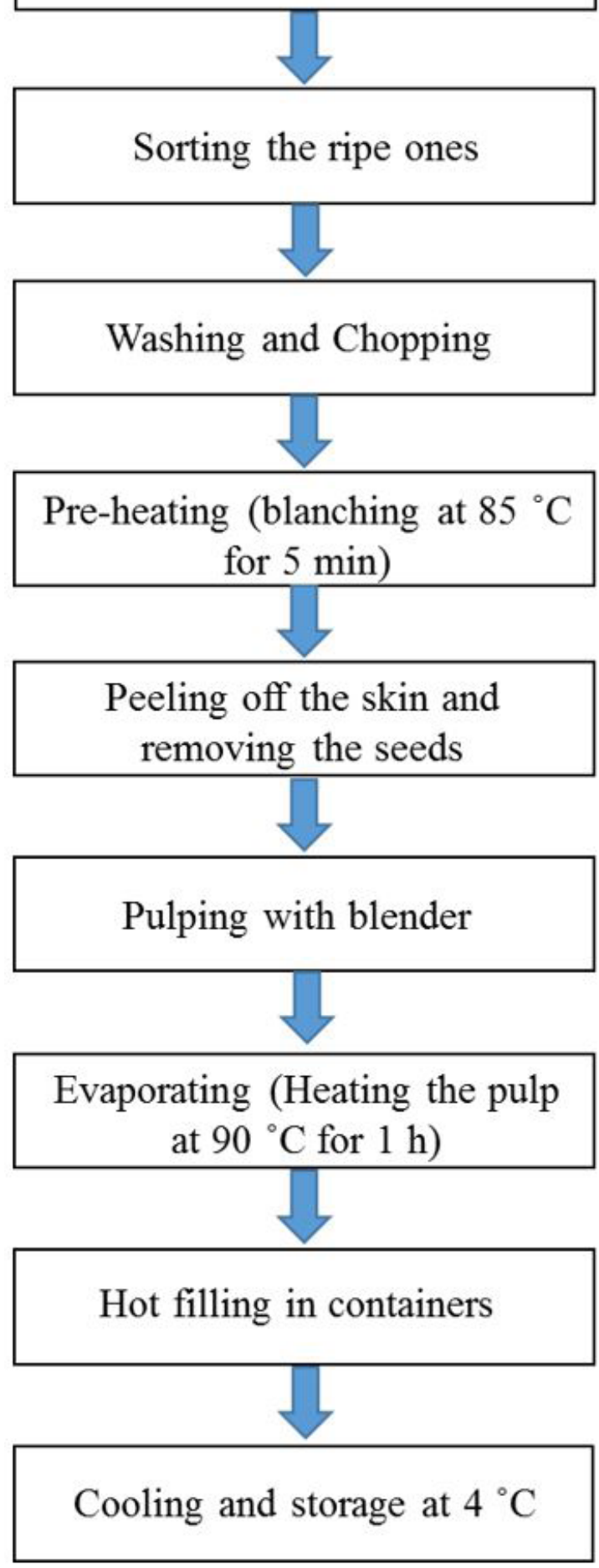

Figure 1. Flow diagram for tomato paste production. 


\subsection{Chemical composition of minced meat}

Proximate composition of minced chicken samples was measured using official methods of AOAC. To determine the moisture content and crude ash of the minced meat samples a warm air oven at $103{ }^{\circ} \mathrm{C}$ and $550{ }^{\circ} \mathrm{C}$, respectively was used (Association of Official Analytical Chemists, 2002). Lipid content was determined by the method of Bligh \& Dyer (1959). To measure the crude protein, the nitrogen content determined by Kjeldahl's method was converted (Association of Official Analytical Chemists, 2005). All analyses were performed in triplicate.

\subsection{Analysis of peroxide value of raw chicken breast sausage}

The peroxide content was determined in the total lipid extracts according to Prasetyo et al. (2008). Results were expressed in meq $\mathrm{O}_{2} / \mathrm{kg}$ lipid. Briefly, $25 \mathrm{~g}$ of raw chicken sausage were homogenized with $100 \mathrm{ml}$ isopropanal and hexane and then centrifuged. The supernatant was gathered in a container and evaporated overnight. Extracted lipids were used for peroxide values and Thiobarbituric acid reactive substances analysis of raw chicken breast product.

\subsection{Thiobarbituric Acid Reactive Substances (TBARS)}

TBARS acid reactive substances were evaluated the method of Prasetyo et al. (2008) with some modification. Briefly, $5 \mathrm{~g}$ of chicken sausage samples was mixed with $12.5 \mathrm{~mL}$ of $20 \%$ TCA solution and homogenized for $30 \mathrm{~s}$ set at high speed and then was filtered using a Whatman number 1 filter paper. Two milliliters of the filtrate were transferred into a test tube; two milliliters ( $2 \mathrm{ML})$ of TBA solution $(0.02 \mathrm{M})$ were then added and incubated in the dark place for $90 \mathrm{~min}$ at $20^{\circ} \mathrm{C}$ and afterward absorbance of samples was measured at $532 \mathrm{~nm}$. TBARS values were recorded as mg malondialdehyde/kg sample (Jouki et al., 2014c). Each TBARS value represents the mean value of at least three samples taken from different treatments.

\subsection{Color measurement}

The color values of the raw chicken sausage samples were determined by a Minolta Chromameter (Model CR-400, Japan) from the surface of the sausage samples (Jouki et al., 2014a). The color parameters were reported by CIE L (lightness/darkness), a (redness/ greenness), and b (yellowness/blueness) coordinates. White standard plate $(\mathrm{L}=97.94, \mathrm{a}=-0.13, \mathrm{~b}=0.94)$ was used for the calibration of the device. At least four replications were set up for each sample.

\subsection{Sensory evaluation}

Sensory evaluation was carried out by 9 trained panelists (including 5 women and 4 men, food science specialists, age 25-35) were asked to determine the raw chicken breast sausage scores with a 5-point hedonic scale for colour, odour, texture and overall acceptability using standard questionnaire. The scores ( $1=$ dislike very much, $2=$ dislike a little, $3=$ neither like nor dislike, $4=$ like a little, and 5= like very much) for taste, color, odor and overall acceptability were given by the expert panelists (Meilgaard et al., 1999). Raw chicken sausage samples were taken for the analysis after 1, 3, 7 and 14 days of storage.

\subsection{Statistical analysis}

A minimum of three observations were collected unless specified otherwise. The experimental data were statistically analyzed using SPSS statistical software (version 21.0; SPSS, Inc., Chicago, IL). Duncan's multiple range test and $\mathrm{P}$ value $<0.05$ were used to compare the differences among means. Also, the correlation coefficient analysis was done between the different parameters.

\section{Results and discussion}

\subsection{Proximate composition}

The results of chemical composition for raw chicken breast meat was determined. Moisture, protein, lipid and ash contents of the chicken meat product averaged 74.69, 20.60, 2.05 and $1.17 \%$, respectively. Our results are in good agreement with those reported by Chen et al. (2016), Petracci et al. (2014) and Prasetyo et al. (2008).

\subsection{Antioxidant activity of tomato paste}

DPPH radical-scavenging abilities of tomato paste at different concentrations (1,2 and 10\%) was measured. All tested samples showed high scavenging activity. Their scavenging activities were, $34 \%, 50 \%$ and $74 \%$, respectively. These results indicate that tomato paste has a noticeable effect on scavenging free radicals. This is probably due to the high amount of lycopene and phenolic compounds (Elbadrawy \& Sello, 2016). Al-Wandawi et al. (1985) found that tomato pulp contains high levels of lycopene. In this part, $\mathrm{IC}_{50}$ was also determined. According to $\mathrm{IC}_{50}$, tomato paste could inhibit free radicals at $20 \mathrm{mg} / \mathrm{ml}$ concentrations. Determination of the half-maximal (50\%) inhibitory concentration $\left(\mathrm{IC}_{50}\right)$ is essential for understanding the nutritional and biological characteristics of an active agent. It has been stated that the scavenging activity on the radical is correlated to the substitution of the hydroxyl groups in the aromatic rings of phenols. It can be related to their ability for hydrogen-denoting (Brand-Williams et al., 1995).

\subsection{Peroxide Value $(\mathrm{PV})$}

Peroxide value is one of the most tests used for the measurement of primary oxidation in food. In this study, oxidation degree on raw chicken breast sausages was determined by measuring peroxide value at $4{ }^{\circ} \mathrm{C}$ for 14 days of storage. Table 1 shows the effect of tomato paste on the peroxide value in raw chicken sausage samples during storage period. As illustrated by Kumar et al. (2015), in the process of lipid oxidation, unsaturated fatty acids are oxidized and hydroperoxides are formed that decompose rapidly, resulting in a large number of secondary compounds including hydrocarbons, aldehydes, ketones, alcohols, esters and acids. These compounds cause unpleasant smell in meat products. Peroxide values were affected by storage time and the presence or absence of TP (Table 1). No significant difference $(P \geq 0.05)$ was observed between the samples in the first day of storage. Peroxide values increased for all samples until day 14 . As previously has been reported, tomato paste showed good antioxidant activity (Elbadrawy \& Sello, 2016). 
Table 1. Peroxide values (meq $\mathrm{O}_{2} / \mathrm{kg}$ ) of chicken sausage samples during storage time ${ }^{\mathrm{a}}$.

\begin{tabular}{lcccc}
\hline \multicolumn{1}{c}{ Samples } & Day 1 & Day 3 & Day 7 & Day 14 \\
\hline Control & $2.83 \pm 0.58 \mathrm{a}, \mathrm{C}$ & $6.50 \pm 0.87 \mathrm{a}, \mathrm{B}$ & $15.50 \pm 3.46 \mathrm{a}, \mathrm{A}$ & $15.17 \pm 2.31 \mathrm{a}, \mathrm{A}$ \\
Incorporated with 1\% TP & $2.81 \pm 0.28 \mathrm{a}, \mathrm{D}$ & $4.33 \pm 0.29 \mathrm{~b}, \mathrm{C}$ & $6.67 \pm 0.29 \mathrm{~b}, \mathrm{~B}$ & $7.83 \pm 0.29 \mathrm{~b}, \mathrm{~A}$ \\
Incorporated with 2\% TP & $3.16 \pm 0.58 \mathrm{a}, \mathrm{B}$ & $4.33 \pm 0.22 \mathrm{~b}, \mathrm{~A}$ & $4.16 \pm 0.29 \mathrm{c}, \mathrm{A}$ & $4.50 \pm 0.29 \mathrm{c}, \mathrm{A}$ \\
Incorporated with 10\% TP & $2.19 \pm 0.59 \mathrm{a}, \mathrm{B}$ & $2.65 \pm 0.57 \mathrm{c}, \mathrm{B}$ & $4.47 \pm 0.29 \mathrm{c}, \mathrm{A}$ & $4.82 \pm 0.26 \mathrm{c}, \mathrm{A}$ \\
\hline
\end{tabular}

Note: a-d: significant different between treatment groups within a storage period (in a column) $(P<0.05)$. A-D: significant difference between storage time within a treatment group (in a row) $(P<0.05)$. ${ }^{a}$ Data are expressed as mean \pm Standard Deviation $(\mathrm{SD})(\mathrm{n}=3)$.

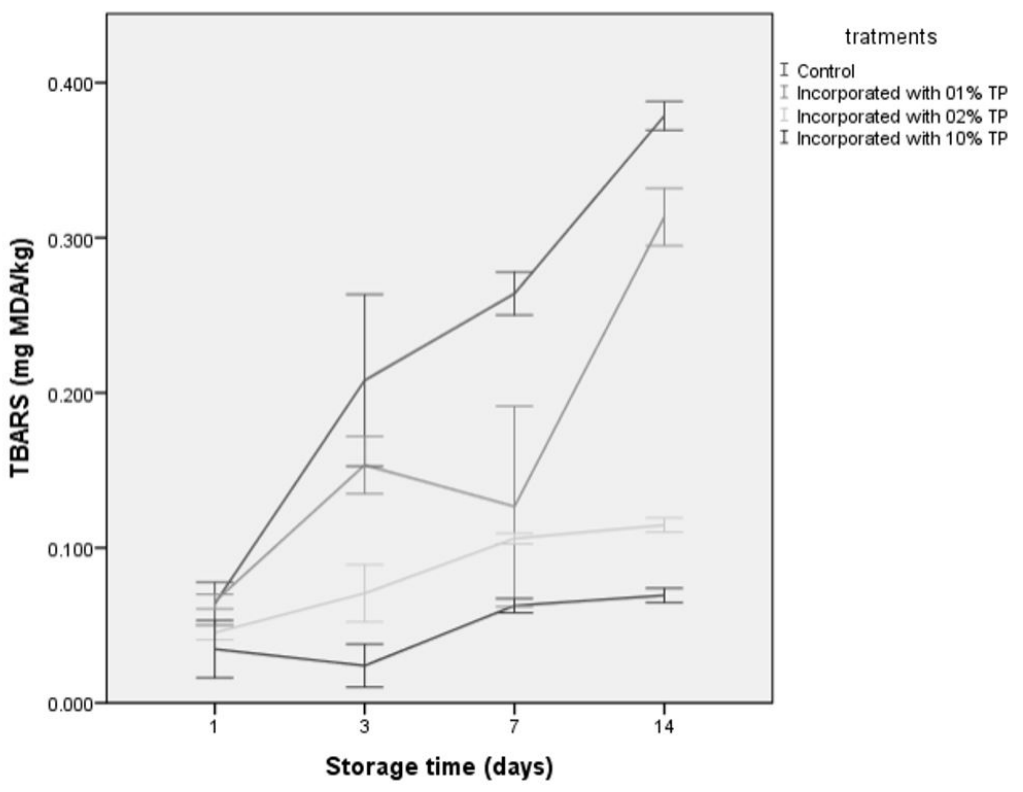

Figure 2. TBARS changes in control and treated chicken sausage during 14 days of storage at $4{ }^{\circ} \mathrm{C}$.

Peroxide values varied for all treatments except control and remained lower than 8 meq $\mathrm{O}_{2} / \mathrm{kg}$ throughout the storage time (14 d). Storage time had a significant effect on the PV of chicken sausage samples, nonetheless PVs in all treated samples were well below the proposed acceptable level of 10 meq peroxide $/ \mathrm{kg}$ meat fat (Jouki et al., 2014c). The results of our study were consistent with those of Teets \& Were (2008), who reported that almond skin powder at concentration of $10 \%$ was effective in retarding the production of primary lipid oxidation products in chicken sausage samples. During refrigerated storage, formation of lipid oxidation products increased from 2.9 to $15.2 \mathrm{meq} \mathrm{O}_{2} / \mathrm{kg}$ for PV.

\subsection{Changes in Thiobarbituric Acid Reactive Substances (TBARS)}

TBARS is an index of lipid oxidation. It is applied as an indicator to evaluate the degree of progression of secondary lipid oxidation (Jeon et al., 2002). The changes in TBARS of control and treated meat samples during storage are presented in Figure 2.

The initial TBARS value was $0.064 \mathrm{mg}$ MDA/ $\mathrm{kg}$ for the chicken breast sausage which was similar to that value reported for rainbow trout by Teets \& Were (2008) and Chouliara et al. (2008). The TBARS value of all meat samples increased with storage time; by the end of the storage period (day 14), however, $10 \%$ TP incorporated samples reached significantly $(P<0.05)$ lower TBA value of $0.069 \mathrm{mg}$ of malonaldehyde equivalents $/ \mathrm{kg}$ of tissue in comparison with the control or meat samples containing
1 and $2 \%$ TP, which attained a higher level of $0.38,0.31$ and $0.11 \mathrm{mg}$ of malonaldehyde equivalents/kg of tissue, respectively (Figure 2).

Tang et al. (2001) showed that even higher values of $0.5-1.6 \mathrm{mg} / \mathrm{kg}$ meat over 10 days of cold storage in raw chicken. It has been proposed that the maximum level of TBARS value indicating good quality of the meat is $3 \mathrm{mg} \mathrm{MDA} / \mathrm{kg}$ of tissue (Chouliara et al., 2008).

Perumalla \& Hettiarachchy (2011) stated that the antioxidant activity of phenolic compounds has been attributed to assorted mechanisms. These include preventing the start of the radical chain, the binding of transition metal ion catalysts, the decomposition of peroxides and the interaction with free radicals. Tomato is high in antioxidant activity, due to a high content of phenolic acids and flavonoids (Giovanelli \& Paradiso, 2002). So, this could be the reason for the decrease in oxidation in treated meat product.

\subsection{Color measurements}

Marinating treatment of raw chicken sausage was found to result in an altered appearance and all of the treated samples had higher $\mathrm{a}^{*}$ and $\mathrm{b}^{*}$ values indicating a more red color. Color parameters of control chicken sausage (untreated) was: $\mathrm{L}^{*}=75.33$, $\mathrm{a}^{\star}=3.34, \mathrm{~b}^{\star}=7.11$, respectively. In accordance, the enriched chicken sausage were found to have lower $\mathrm{L}^{*}$ values, although this decrease was not significant $(P \geq 0.05)$. The color parameters changed from the raw chicken sausage to the enriched meat 
and were affected by the packaging or storage time. The results showed that there were significant differences $(P<0.05)$ in the colour parameters of the raw chicken breast sausage at the first day of storage. The colour evaluation of meat samples showed that the concentration of TP had significant $(P<0.05)$ effects on the colour of raw chicken sausage samples (Table 2). Similar results have been observed in previous studies by adding tomato products to the color changes of grilled turkey breast
(Skiepko et al., 2016), minced chicken (Alves et al., 2012), beef (Østerlie \& Lerfall, 2005) and pork (An et al., 2019) samples.

\subsection{Sensory characteristics}

The average sensory scores of all panelists are shown in Figure 3. The results showed that there were significant differences $(P<0.05)$ in the sensory attributes of the raw chicken

Table 2. Colour parameters ( $\mathrm{L}$, a and b) of chicken sausage samples during storage time $\mathrm{e}^{\mathrm{a}}$.

\begin{tabular}{|c|c|c|c|c|}
\hline \multicolumn{5}{|c|}{$\mathrm{L}$} \\
\hline Samples & Day 1 & Day 3 & Day 7 & Day 14 \\
\hline Control & $75.33 \pm 1.77 \mathrm{a}, \mathrm{A}$ & $74.39 \pm 0.76 \mathrm{a}, \mathrm{AB}$ & $72.30 \pm 1.41 \mathrm{a}, \mathrm{B}$ & $70.23 \pm 1.31 \mathrm{a}, \mathrm{c}$ \\
\hline Incorporated with $1 \% \mathrm{TP}$ & $75.40 \pm 0.87 \mathrm{a}, \mathrm{A}$ & $73.90 \pm 0.54 \mathrm{a}, \mathrm{B}$ & $72.28 \pm 0.94 \mathrm{a}, \mathrm{C}$ & $72.98 \pm 1.22 \mathrm{~b}, \mathrm{C}$ \\
\hline Incorporated with $2 \% \mathrm{TP}$ & $74.98 \pm 1.10 \mathrm{a}, \mathrm{A}$ & $73.76 \pm 0.78 \mathrm{a}, \mathrm{AB}$ & $73.11 \pm 0.81 \mathrm{a}, \mathrm{AB}$ & $72.65 \pm 0.89 \mathrm{~b}, \mathrm{~B}$ \\
\hline Incorporated with $10 \% \mathrm{TP}$ & $74.11 \pm 0.91 \mathrm{a}, \mathrm{A}$ & $72.70 \pm 1.04 \mathrm{~b}, \mathrm{~A}$ & $72.65 \pm 1.11 \mathrm{a}, \mathrm{A}$ & $72.44 \pm 1.02 \mathrm{~b}, \mathrm{~A}$ \\
\hline \multicolumn{5}{|c|}{$\mathrm{a}$} \\
\hline Control & $3.34 \pm 0.23 \mathrm{c}, \mathrm{A}$ & $3.10 \pm 0.26 \mathrm{~d}, \mathrm{AB}$ & $3.01 \pm 0.22 \mathrm{~d}, \mathrm{AB}$ & $2.98 \pm 0.12 \mathrm{c}, \mathrm{AB}$ \\
\hline Incorporated with $1 \% \mathrm{TP}$ & $3.45 \pm 0.11 \mathrm{c}, \mathrm{A}$ & $3.22 \pm 0.12 c, A$ & $3.83 \pm 0.58 c, A$ & $3.33 \pm 0.58 c, A$ \\
\hline Incorporated with $2 \% \mathrm{TP}$ & $5.14 \pm 0.24 \mathrm{~b}, \mathrm{~A}$ & $5.33 \pm 0.29 \mathrm{~b}, \mathrm{~A}$ & $5.27 \pm 0.29 \mathrm{~b}, \mathrm{~A}$ & $5.19 \pm 0.29 \mathrm{~b}, \mathrm{~A}$ \\
\hline Incorporated with $10 \% \mathrm{TP}$ & $7.34 \pm 0.13 \mathrm{a}, \mathrm{A}$ & $7.14 \pm 0.22 \mathrm{a}, \mathrm{A}$ & $7.16 \pm 0.29 \mathrm{a}, \mathrm{A}$ & $6.44 \pm 0.28 \mathrm{a}, \mathrm{B}$ \\
\hline \multicolumn{5}{|c|}{$\mathrm{b}$} \\
\hline Control & $7.43 \pm 0.13 \mathrm{~b}, \mathrm{D}$ & $8.35 \pm 0.35 \mathrm{a}, \mathrm{C}$ & $9.24 \pm 0.10 \mathrm{a}, \mathrm{B}$ & $11.97 \pm 0.21 \mathrm{a}, \mathrm{A}$ \\
\hline Incorporated with $1 \% \mathrm{TP}$ & $8.35 \pm 0.27 \mathrm{a}, \mathrm{B}$ & $8.38 \pm 0.16 \mathrm{a}, \mathrm{B}$ & $8.84 \pm 0.21 \mathrm{~b}, \mathrm{~A}$ & $9.64 \pm 0.22 \mathrm{~b}, \mathrm{~A}$ \\
\hline Incorporated with $2 \% \mathrm{TP}$ & $8.45 \pm 0.29$ a,A & $8.48 \pm 0.20 \mathrm{a}, \mathrm{A}$ & $8.41 \pm 0.53 \mathrm{~b}, \mathrm{~A}$ & $8.39 \pm 0.19 \mathrm{c}, \mathrm{A}$ \\
\hline Incorporated with $10 \% \mathrm{TP}$ & $8.75 \pm 0.33 \mathrm{a}, \mathrm{A}$ & $8.57 \pm 0.16 \mathrm{a}, \mathrm{A}$ & $8.63 \pm 0.11 \mathrm{~b}, \mathrm{~A}$ & $8.84 \pm 0.34 \mathrm{c}, \mathrm{A}$ \\
\hline
\end{tabular}

Note: a-d: significant different between treatment groups within a storage period (in a column) $(P<0.05)$. A-D: significant difference between storage time within a treatment group (in a row) $(P<0.05) .{ }^{a}$ Data are expressed as mean \pm Standard Deviation $(S D)(n=3)$.
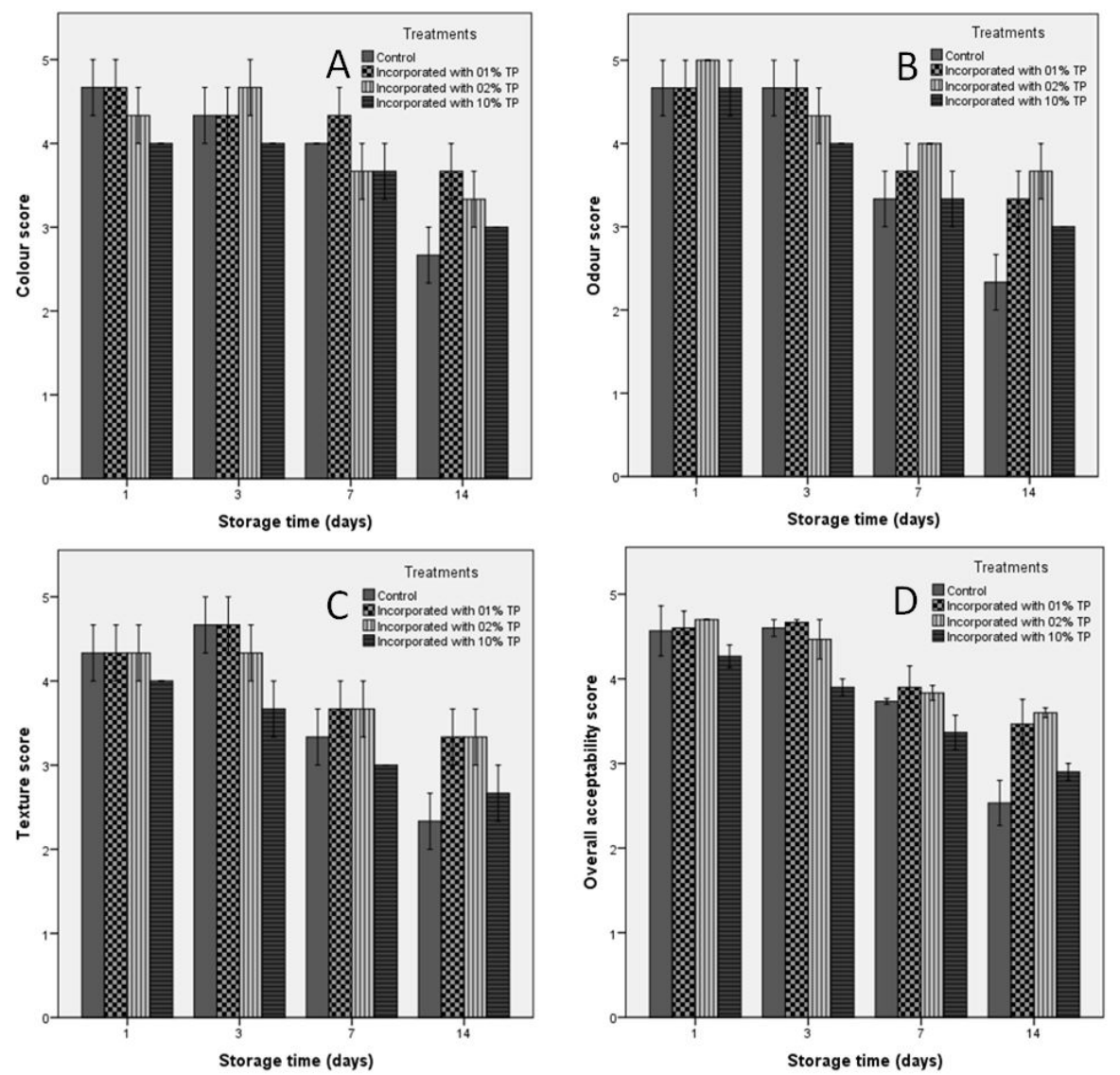

Figure 3. Effect of tomato paste (TP) concentrations on sensory scores of chicken sausage during 14 days of storage. Odour (A), colour (B), texture (C) and overall acceptability (D). 
breast sausage samples at the first day of storage. The sensory evaluation of samples showed that the concentration of TP had significant $(P<0.05)$ effects on the colour, odour, texture and overall acceptability of raw chicken breast sausage samples (Figure 3A-D). All treated samples had desirability scores in the range 4-5 (which equals little like to very like) suggesting that tomato paste incorporation into raw chicken sausage up to the $2 \%$ level did not result in any adverse effect on colour, texture and overall acceptability characteristics.

The panelists preferred chicken breast sausage containing $2 \%$ of TP. Higher levels of TP altered the visual appearance. However, the panelist could not identify the differences in the odour and colour between control and the sample enriched with $1 \%$ and $2 \%$ TP. The control had the lowest colour and odour scores at the end of storage. As has been reported by Østerlie \& Lerfall (2005), enriched chopped beef with lycopene extracted from tomatoes can increase shelf life, improve the taste and color of the food product and be considered as a health benefit. So, the tomato paste used in this study could cover the unfavorable sensory attributes in chicken sausage samples. The higher scores were related to the sample containing $2 \% \mathrm{TP}$ at the end of storage.

To minimize the visual impact of TP addition into raw chicken breast sausage, application of a lower concentration of tomato paste due to the high antioxidant activity can be used. These changes could minimize the effect of TP on colour of chicken breast sausage which could therefore increase consumer acceptability.

\section{Conclusion}

The results of this study showed that tomato paste has remarkable antioxidant activity. Enrichment of chicken meat sausage by tomato paste at concentration of $2 \%$ and $1 \%$ pectin enhanced its quality by inhibition of lipid oxidation and undesirable appearance changes. Lipid oxidation in refrigerated raw chicken breast sausage was indicated by PV and TBARS over 14 days of analysis. Moreover, the protective effect of $10 \%$ TP against lipid oxidation in chicken sausage was more pronounced than other samples. However, the application of tomato paste at higher concentrations might be limited due to its effect on colour of the meat products and uneven distribution throughout the raw chicken breast sausage. Based on the results achieved, TP could be a good candidate as a natural antioxidant to prevent oxidative and colour changes in raw chicken breast sausage during storage. In summary, minced chicken meat enriched by TP were acceptable under refrigerated storage for 14 days, compared to less than 7 days for control sausage samples.

\section{Acknowledgements}

We gratefully acknowledge the Department of Food Science and Technology, Islamic Azad University, North Tehran Branch, Iran for financial support of this work.

\section{References}

Alves, A. B., Bragagnolo, N., Silva, M. G., Skibsted, L. H., \& Orlien, V. (2012). Antioxidant protection of high-pressure processed minced chicken meat by industrial tomato products. Food and Bioproducts Processing, 90(3), 499-505. http://dx.doi.org/10.1016/j.fbp.2011.10.004.
Al-Wandawi, H., Abdul-Rahman, M., \& Al-Shaikhly, K. (1985). Tomato processing wastes as essential raw materials source. Journal of Agricultural and Food Chemistry, 33(5), 804-807. http://dx.doi. org/10.1021/jf00065a009.

An, B. K., Kim, D. H., Joo, W. D., Kang, C. W., \& Lee, K. W. (2019). Effects of lycopene and tomato paste on oxidative stability and fatty acid composition of fresh belly meat in finishing pigs. Italian Journal of Animal Science, 18(1), 630-635. http://dx.doi.org/10.108 0/1828051X.2018.1549963.

Association of Official Analytical Chemists - AOAC. (2002). Official Method of Analysis (14th ed.). Washington, DC: AOAC.

Association of Official Analytical Chemists - AOAC. (2005). Official Method of Analysis (17th ed.). Washington, DC: AOAC.

Bligh, E. G., \& Dyer, W. J. (1959). A rapid method of total lipid extraction and purification. Canadian Journal of Biochemistry and Physiology, 37(8), 911-917. http://dx.doi.org/10.1139/o59-099. PMid:13671378.

Brand-Williams, W., Cuvelier, M., \& Berset, C. (1995). Use of a free radical method to evaluate antioxidant activity. LebensmittelWissenschaft + Technologie, 28(1), 25-30. http://dx.doi.org/10.1016/ S0023-6438(95)80008-5.

Brannan, R. G. (2008). Effect of grape seed extract on physicochemical properties of ground, salted, chicken thigh meat during refrigerated storage at different relative humidity levels. Journal of Food Science, 73(1), C36-C40. http://dx.doi.org/10.1111/j.1750-3841.2007.00588.x. PMid:18211347.

Chen, Y., Qiao, Y., Xiao, Y. U., Chen, H., Zhao, L., Huang, M., \& Zhou, G. (2016). Differences in physicochemical and nutritional properties of breast and thigh meat from crossbred chickens, commercial broilers, and spent hens. Asian-Australasian Journal of Animal Sciences, 29(6), 855-864. http://dx.doi.org/10.5713/ajas.15.0840. PMid:26954114.

Chen, J., Song, Y., \& Zhang, L. (2013). Lycopene/tomato consumption and the risk of prostate cancer: a systematic review and metaanalysis of prospective studies. Journal of Nutritional Science and Vitaminology, 59(3), 213-223. http://dx.doi.org/10.3177/jnsv.59.213. PMid:23883692.

Chouliara, E., Badeka, A., Savvaidis, I., \& Kontominas, M. G. (2008). Combined effect of irradiation and modified atmosphere packaging on shelf-life extension of chicken breast meat: Microbiological, chemical and sensory changes. European Food Research and Technology, 226(4), 877-888. http://dx.doi.org/10.1007/s00217-007-0610-3.

Du, H., \& Li, H. (2008). Antioxidant effect of cassia essential oil on deepfried beef during the frying process. Meat Science, 78(4), 461-468. http://dx.doi.org/10.1016/j.meatsci.2007.07.015. PMid:22062466.

Elbadrawy, E., \& Sello, A. (2016). Evaluation of nutritional value and antioxidant activity of tomato peel extracts. Arabian Journal of Chemistry, 9(2), S1010-S1018. http://dx.doi.org/10.1016/j. arabjc.2011.11.011.

Gann, P. H., Ma, J., Giovannucci, E., Willett, W., Sacks, F. M., Hennekens, C. H., \& Stampfer, M. J. (1999). Lower prostate cancer risk in men with elevated plasma lycopene levels: results of a prospective analysis. Cancer Research, 59(6), 1225-1230. PMid:10096552.

Giovanelli, G., \& Paradiso, A. (2002). Stability of dried and intermediate moisture tomato pulp during storage. Journal of Agricultural and Food Chemistry, 50(25), 7277-7281. http://dx.doi.org/10.1021/ jf025595r. PMid:12452644.

Jeon, Y. W., Jung, J. W., Kang, M., Chung, I. K., \& Lee, W. (2002). NMR studies on antitumor drug candidates, berberine and berberrubine. Bulletin of the Korean Chemical Society, 23(3), 391-394. http://dx.doi. org/10.5012/bkcs.2002.23.3.391. 
Jo, K., Lee, J., \& Jung, S. (2018). Quality Characteristics of Low-salt Chicken Sausage Supplemented with a Winter Mushroom Powder. Korean Journal for Food Science of Animal Resources, 34(4), 768-779. http://dx.doi.org/10.5713/ajas.19.0193.

Jouki, M. (2013). Evaluation of gamma irradiation and frozen storage on microbial load and physico-chemical quality of turkey breast meat. Radiation Physics and Chemistry, 85, 243-245. http://dx.doi. org/10.1016/j.radphyschem.2012.12.009.

Jouki, M., Mortazavi, S. A., Tabatabaei Yazdi, F., Koocheki, A., \& Khazaei, N. (2014a). Use of quince seed mucilage edible films containing natural preservatives to enhance physico-chemical quality of rainbow trout fillets during cold storage. Food Science and Human Wellness, 3(2), 65-72. http://dx.doi.org/10.1016/j.fshw.2014.05.002.

Jouki, M., \& Tabatabaei Yazdi, F. (2014a). The effect of gamma irradiation and vacuum packaging upon selected quality traits of refrigerated ostrich meat. Part 1. Microbial assessment. Animal Science Papers and Reports, 32(1), 81-89.

Jouki, M., \& Tabatabaei Yazdi, F. (2014b). The effect of gamma irradiation and vacuum packaging upon selected quality traits of refrigerated ostrich meat. Part 2. Colour, texture and lipid oxidation properties. Animal Science Papers and Reports, 32(2), 161-171.

Jouki, M., Tabatabaei Yazdi, F., Mortazavi, S. A., \& Koocheki, A. (2014b). Quince seed mucilage films incorporated with oregano essential oil: physical, thermal, barrier, antioxidant and antibacterial properties. Food Hydrocolloids, 36, 9-19. http://dx.doi.org/10.1016/j. foodhyd.2013.08.030.

Jouki, M., Tabatabaei Yazdi, F., Mortazavi, S. A., Koocheki, A., \& Khazaei, N. (2014c). Effect of quince seed mucilage edible films incorporated with oregano or thyme essential oil on shelf life extension of refrigerated rainbow trout fillets. International Journal of Food Microbiology, 174, 88-97. http://dx.doi.org/10.1016/j. ijfoodmicro.2014.01.001. PMid:24463155.

Kim, S. J., Cho, A. R., \& Han, J. (2013). Antioxidant and antimicrobial activities of leafy green vegetable extracts and their applications to meat product preservation. Food Control, 2(1), 112-120. http:// dx.doi.org/10.1016/j.foodcont.2012.05.060.

Kim, H. S., \& Chin, K. B. (2017). Evaluation of antioxidative activity of various levels of ethanol extracted tomato powder and application to pork patties. Han-gug Chugsan Sigpum Hag-hoeji, 37(2), 242-253. http://dx.doi.org/10.5851/kosfa.2017.37.2.242. PMid:28515648.

Kumar, Y., Yadav, D. N., Ahmad, T., \& Narsaiah, K. (2015). Recent Trends in the Use of Natural Antioxidants for Meat and Meat Products. Comprehensive Reviews in Food Science and Food Safety, 14(6), 796-812. http://dx.doi.org/10.1111/1541-4337.12156.

Maqsood, S., \& Benjakul, S. (2011). Comparative studies on molecular changes and pro-oxidative activity of haemoglobin from different fish species as influenced by pH. Food Chemistry, 124(3), 875-883. http://dx.doi.org/10.1016/j.foodchem.2010.07.011.

Marcinkowska-Lesia, M., Zdanowska-Sąsiadek, Ż., Stelmasiak, A., Damaziak, K., Michalczuk, M., Poławska, E., Wyrwisz, J., \& Wierzbicka, A. (2016). Effect of packaging method and cold-storage time on chicken meat quality. Cited - Journal of Food, 14(1), 41-46.

Mariutti, L. R. B., Nogueira, G. C., \& Bragagnolo, N. (2011). Lipid and cholesterol oxidation in chicken meat are inhibited by sage but not by garlic. Journal of Food Science, 76(6), C909-C15. http://dx.doi. org/10.1111/j.1750-3841.2011.02274.x. PMid:22417489.

Martinez-Valvercle, I., Periage, M. J., Provan, G., \& Chesson, A. (2002). Phenolic compounds, Lycopene and antioxidant activities in commercial varieties of tomato (lycopersicon esculentum). Journal of the Science of Food and Agriculture, 82(3), 323-330. http://dx.doi. org/10.1002/jsfa.1035.
Marzoni, M., Chiarini, R., Castillo, A., Romboli, I., De Marco, M., \& Schiavone, A. (2014). Effects of dietary natural antioxidant supplementation on broiler chicken and Muscovy duck meat quality. Animal Science Papers and Reports, 32(4), 359-368.

Masuda, T., Inaba, Y., \& Takeda, Y. (2001). Antioxidant mechanism of carnosic acid: Structural identification of two oxidation products. Journal of Agricultural and Food Chemistry, 49(11), 5560-5565. http://dx.doi.org/10.1021/jf010693i. PMid:11714360.

Meilgaard, M., Civille, G. V., \& Carr, B. T. (1999). Selection and training of panel members. In M. C. Meilgaard, B. T. Carr \& G. V. Civill (Eds.). Sensory evaluation techniques (pp. 133-158). Boca Raton: CRC Press Inc. http://dx.doi.org/10.1201/9781439832271.ch9.

Murcia, M. A., Egea, I., Romojaro, F., Parras, P., Jimenez, A. M., \& Martinez-Tome, M. (2004). Antioxidant evaluation in dessert spices compared with common food additives. Influence of irradiation procedure. Journal of Agricultural and Food Chemistry, 52(7), 1872-1881. http://dx.doi.org/10.1021/jf0303114. PMid:15053523.

Nachtigall, F. M., Vidal, V. A. S., Pyarasani, R. D., Domínguez, R., Lorenzo, J. M., Pollonio, M. A. R., \& Santos, L. S. (2019). Substitution Effects of $\mathrm{NaCl}$ by $\mathrm{KCl}$ and $\mathrm{CaCl}_{2}$ on Lipolysis of Salted Meat. Foods, 8(12), 595-615. http://dx.doi.org/10.3390/foods8120595. PMid:31756914.

Naveena, B. M., Sen, A. R., Vaithiyanathan, S., Babji, Y., \& Kondaiah, N. (2008). Comparative efficacy of pomegranate juice, pomegranate rind powder extract and BHT as antioxidants in cooked chicken patties. Meat Science, 80(4), 1304-1308. http://dx.doi.org/10.1016/j. meatsci.2008.06.005. PMid:22063872.

Perumalla, A. V., \& Hettiarachchy, N. S. (2011). Green tea and grape seed extracts - Potential applications in food safety and quality. Food Research International, 44(4), 827-839. http://dx.doi.org/10.1016/j. foodres.2011.01.022.

Petracci, M., Mudalal, S., Babini, E., \& Cavani, C. (2014). Effect of White Striping on Chemical Composition and Nutritional Value of Chicken Breast Meat. Italian Journal of Animal Science, 13(1), 179-183. http://dx.doi.org/10.4081/ijas.2014.3138.

Prasetyo, M., Chia, M., Hughey, C., \& Were, L. M. (2008). Utilization of electron beam irradiated almond skin powder as a natural antioxidant in ground top round beef. Journal of Food Science, 73(1), T1-T6. http://dx.doi.org/10.1111/j.1750-3841.2007.00553.x. PMid:18211377.

Østerlie, J., \& Lerfall, M. (2005). Lycopene from tomato products added minced meat: Effect on storage quality and colour. Food Research International, 38(8-9), 925-929. http://dx.doi.org/10.1016/j. foodres.2004.12.003.

Skiepko, N., Chwastowska-Siwiecka, I., Kondratowicz, J., \& Mikulski, D. (2016). The effect of lycopene addition on the chemical composition, sensory attributes and physicochemical properties of steamed and grilled turkey breast. Brazilian Journal of Poultry Science, 18(2), 319-330. http://dx.doi.org/10.1590/1806-9061-2015-0010.

Tang, S., Sheehan, D., Buckley, D. J., Morrissey, P. A., \& Kerry, J. P. (2001). Anti-oxidant activity of added tea catechins on lipid oxidation of raw minced red meat, poultry and fish muscle. International Journal of Food Science \& Technology, 36(6), 685-692. http://dx.doi. org/10.1046/j.1365-2621.2001.00497.x.

Teets, A. S., \& Were, L. M. (2008). Inhibition of lipid oxidation in refrigerated and frozen salted raw minced chicken breasts with electron beam irradiated almond skin powder. Meat Science, 80(4), 1326-1332. http://dx.doi.org/10.1016/j.meatsci.2008.06.010. PMid:22063875.

Xu, X., Li, J., Wang, X., Wang, S., Meng, S., Zhu, Y., Liang, Z., Zheng, X., \& Xie, L. (2016). Tomato consumption and prostate cancer risk: a systematic review and meta-analysis. Scientific Reports, 6(1), 37091. http://dx.doi.org/10.1038/srep37091. PMid:27841367. 